\title{
Design for the Environment: Nembe Se in the Niger Delta Region of Nigeria and it's Cultural Heritage as Resource for Sustainability in the 21st Century.
}

\author{
Dr. Pamela I. Cyril-Egware \\ Department of Fine Arts \& Design, University of Port Harcourt, Choba, Rivers State. \\ Email: picegware@yahoo.com; Phone: +2348037230664
}

\begin{abstract}
Nembe Se is a traditional Kingdom in the Southern part of Nigeria, East of the Niger Delta. They occupy all the Nembe speaking communities in Nembe and Brass Local Government Area of Bayelsa State in Nigeria. The Niger Delta region is a unique ecological zone in Nigeria with an area covering approximately 70,000 square kilometres and makes up to $7.5 \%$ of Nigeria's land mass. It is politically made up of more than 40 ethnic groups and about 250 different dialects. The region is rich in natural resources embedded in their environment and culture which is seen in their social, political, cultural, religious, economic and traditional systems on daily bases, making it a viable tourist attraction if well preserved. The region is posed with a threat to these treasures, hence the ardent need for an alternative means to promote, protect and preserve these resources for tourism, education, research and development, for sustainability. Textiles as a very mobile art is a distinctive human production considered as an ultimate form of material culture and a primary form of documenting indigenous source materials and revealing the identity, history, culture and environment of a people. These could be preserved, reproducing same through such artistic expression as decorative arts, theatrical arts and clothing, leading to industrialization. This paper looks at the cultural heritage of the Niger Delta people with the aim of documenting them in visual form on textiles. Design on textiles from different cultures and the Niger Delta are compared and analyzed with visuals, and a means of preserving them is suggested. The paper observed that the rich cultural heritage of the Niger Delta people if preserved on textiles will serve as a major instrument in their socio-economic development as seen in other nations if the industry and tourism sector is developed and sustained.
\end{abstract}

\section{Keywords: Design, Environment, Niger Delta, Cultural Heritage, Resource, Sustainability}

\section{INTRODUCTION}

This paper examines Design for the Environment: Nembe Se in the Niger Delta Region of Nigeria and it's Cultural Heritage as Resource for Sustainability in the 21st Century. Bell-Gam (2007), in Cyril-Egware (2013) states that the environment is man's life support system and the structure around which man lives and builds the future generations. The environment serves as a motivational force for creative designs and processes which can conveniently be derived from man's response to his natural environment. Textile Design in form of dress and decorative items are used as documentary sources for the cultural heritage of the Niger Delta people for sustainable economic development. Aquatic forms collected as resources from the riverine communities of the Niger Delta were used as representation to document the cultural heritage and environment of the Niger Delta people.

The aquatic forms are fast going extinct as a result of man-made and natural disaster, oil spillage, urbanization, education and religion. The riverine communities in the Niger Delta does not consider the preservation of their cultural heritage as a source of generation wealth and the development of their environment so tourism is not taken seriously. They also do not take museum and court art culture seriously. This paper therefore aims at using cloth production as an alternative medium to document the cultural heritage of the Niger Delta people for sustainable economic development; identity means of highlighting the region for tourism, further research, Industrialisation for the Production of cloth for Nembe se communities in Bayelsa State for job creation which will in turn generate wealth for sustainability and project aquatic forms as cultural heritage for resource generation.

Niger Delta is a unique ecological zone in Nigeria with an area covering approximately 70,000 square kilometres and makes up to $7.5 \%$ of Nigeria's land mass. It is politically made up of a states with some 31 million people of more than 46 ethnic groups and about 250 different dialects visual arts is the documentation of indigenous and contemporary source materials for education, research and development. Textiles suggests 
much about the culture and history of a people in varied and complex designs, techniques and meanings, the tourism sector is the main instrument in the socio-economic development of any nation.

The Niger Delta Region of Nigeria is richly endowed with huge amount of natural resources which can enhance the environment and the people economically, socially, politically and culturally for sustainable development. The environment and the cultural heritage of a people gives the designer a rich choice of materials and inspiration in his designs. This will in turn serve as resource and reserve for sustainability of the cultural heritage of the Niger Delta Region in Nigeria in the 21st century. Such resources seen as cultural heritage include natural and manmade structures which can be seen in the artefacts from archaeological excavations, mangrove forest, the sea, rivers and creeks, beach, plants, aquatic forms and creatures, landscape, seascape historic sites, crude oil and gas, the soil and the weather. Others include, artistic heritage, folk tales, cultural festivals and performances and the history of the people.

Designs inspired by the cultural heritage and environment serve as resource for sustainability in the 21 st century if well preserved and seen as valuable. Derefaka (2012), is of the opinion that it is only when these are preserved that they can be used for such development efforts as promoting cultural and eco tourism that will provide jobs for the teeming unemployed youths. Such designs will highlight, promote, document and pressure the resources of the Niger Delta for posterity. In his pictorial documentation of research sites in Brass Local Government Area of Bayelsa State Derefaka gives an insight about the importance of art in the history of a community. The photographs show parts of Bayelsa State, highlighting the variety and richness of cultural heritage that exists and have called for the need to properly manage and harness then for various developmental purposes in the Niger Delta. Tourists and researcher will be attracted to the environment when such designs are put on textiles, ceramics and other functional materials and preserved as court art, in galleries and museums or in lives of art collectors. These will be useful if recognised as valuable historic cultural heritage of the region.

\section{TEXTILE DESIGN}

The study of Textile Design as an art form has motivated a high degree of aesthetic sensitivity in dissemination of information, preservation of culture and in portraying identity. Talabi (1979), states that one of the principal canon for judging a nation is its artistic heritage. This can be seen in the archaeological excavations at Onyoma in Nembe Local Government Area from AD 1275-1845: Saikiripogu Ewoama in Brass Local Government Area from AD 1000-1600; Agadagbou in Kolokuma/Opokuma Local Government Area in the 16th century AD and Isomabou in Ikirbiri, Ekpetiama in Yenagoa Local Government Area AD 1030-1480. Alagoa (1999). These serve as evidence that people existed in these communities before the coming of the Portuguese. According to Anderson (1999), the Bayelsa region is noted for producing some of the large figure carvings and masks in all of sub-Saharan Africa, as well as originating a style which may indirectly have inspired cubism, a revolutionary movement in Western art. Unfortunately she said, many of the objects that have entered Western collections lack proper documentation. The Fowler museum of cultural History at University of Los Angelis has a number of Ijaw figures, but no record of their origin was kept. The Merseyside County Museums in Liverpool is housing the largest collection of Bayelsa sculpture outside Nigeria, and it is also of the earliest. Anderson also states that a colonial master named A. A. White House assembled it in the vicinity of Wilberforce Island during a 1903 punitive expedition which targeted o pirate known locally as Bebeka-Ola. Another early group of figures she said which belonged to King Josiah Constantine Ockiya of Nembe, where commissioned, as portraits of himself and his family, but he turned them over to Bishop Crowder of the Church Missionary Society when he converted to Christianity in1877. The figure have been dispersed, one is in the National Museum of African Art in Washington C. D and another in the Manchester Museum in England. Anderson (1999). Earlier objects as stated by Anderson are sculpture pieces hence the need for textile design as an alternative source of documenting and preserving the cultural heritage of the people.

Textile design, unlike other art practices, was historically a human professional reaction to environmental necessity, to cover human nakedness. This helped spread the full influence of the practice of textiles at different stages of civilization. Ojo (2002) defined textile design as creative decoration of fabrics and the allied products of clothing, drapes and furniture. He further states that the decoration may be through dyeing, painting, printing, embroidery, or appliqué.

Cyril-Egware (2006) defines textile as the art of making cloth from the fibre stage to the finished fabric or cloth which could be constructed by knitting, plaiting braiding weaving or felting. She further defines textile design as the ordered arrangement and rhythmic repetition of motifs, colour and textiles on fabric.

Cyril-Egware (2013) states that fabric design means adding embellishment to textile fabric, to beautify or add value to it. It is an ordered arrangement and rhythmic repetition of motifs, colours and texture on fabric. It may be the design structure or incorporated as decorative element such as brocade or lace or applied to finished fabrics by embroidery or other needlework or by painting, printing or by resist dyeing. Proper utilization of the elements and principles of design gives a good fabric design. This paper distinguishes textiles as a key area of design in highlighting, promoting, documenting and preserving the resources in the Niger Delta environment for 
posterity. Textiles design as a mobile art goes a long way in information dissemination, either as dress and/or furnishing materials. Other areas that portray textiles in their works are artefacts from archaeological excavations from Onyoma, Saikiripogu, Odoima in Nembe and Brass local government areas of Bayelsa state, have in no small manner helped to identify human existence in the

Niger Delta Region. It has also identified some cultural heritage, occupation, dress style, identified abandoned sites and many more. Alagoa(1999).Archaeologists were able to discover fibers used for woven fabrics at IgboUkwu. Olorukoba \& Uzoagba (1991) is of the opinion that although no trace of cotton was found, which had selvages that indicate a wearing process probably on a loom, the dress fashion of the king of Onyoma was depicted by the excavations at Onyoma. There was evidence of more raffia, beaten back cloth/wool and silk was rare as these are not native to African but brought in by the Dutch in the $17^{\text {th }}$ Century. Shrines are usually made up of a collection of objects and fabrics supposedly to have some magical powers. These are works of the artists and designers which they have sanctified and dedicated as symbols of communication with the supreme being. Olorukoba \& Uzoagba (1991) says they are religious and fetish figures, cult objects, masks as well as objects of everyday use such as stools, bowls, drums, door post, pillars and utensils.

Cultures are identifiable with their textiles which derive inspiration for their culture and environment. These include tales, proverbs, cultural displays currency, religious beliefs and several others. Such fabrics are highly valued and preserved in boxes in Nembe and the whole of Niger Delta as a culture, in museums and galleries at a higher standard. Textiles of identity with symbols used by the Niger Delta people include; Akwa Ocha, pelete bite, kente, ikagi bara (Ikaki) popo, inziri, blangidi and abada.Textiles plays a significant role in the daily lives of every community. Africa textiles have been evidently functional in many respects. It is interwoven with the culture of the people which cuts across religion, education, entertainment, decoration, commerce and industry, social unity and prestige, international understanding, expression of culture, maintenance of civilization. Art is what we make for others to see. Innovation in fabric decoration have in one way or the other served as a source of documentation of the history, culture and environment of the people, thereby exposing its value. This has led to the transformation of textiles inform of surface embellishment, embroidery, beading, sequence and appliqué.

The Niger Delta region is posed with degradation and damage to the eco-system caused by oil exploration, oil spills, oil theft and artisanal refineries. The environment feeds, provides resources and gives comfort so man's life is bound up in his environment and whatever happens to the land happens to his existence and the environment is irreparable to man. Social environment constitutes human settlements and human settlements constitutes major components of the social environment.

How can the people use textiles as a means to preserve and document the Niger Delta environment for posterity?

Of what benefit will it be to the Nembe people if their heritage is documented on fabrics?

\section{Significance}

$>$ Study the environment and transform its natural beautiful features, land marks, historical sites and cultural heritage into tourism assets.

$>$ The rich cultural heritage and natural endowment which are the aquatic forms as described in this paper, are seen and retained as treasures to be developed for maximum national benefits especially if the tourism sector is developed.

$>$ Textiles will be developed as an alternative means for documentation of the cultural heritage of the region.

$>$ This will lead to investors in the textile industry to develop and appreciate the use of symbols and motifs from the Niger Delta region for their designs other than copying existing foreign ones.

$>$ The cultural heritage of environment and the people will be highlighted, promoted and preserved for tourism, research, industry and job creation.

\section{Textiles from other cultures documenting their cultural heritage tagged monumental clothes}

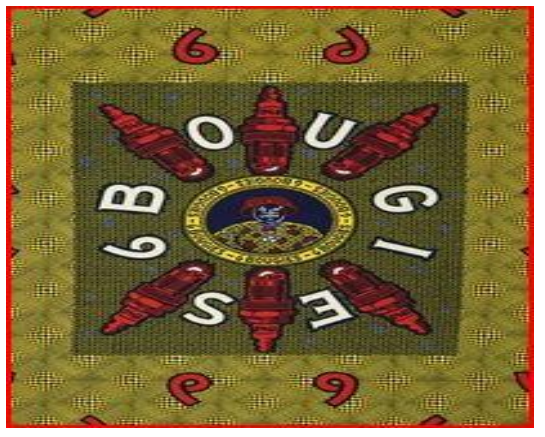

DOI: $10.9790 / 0837-2108111018$

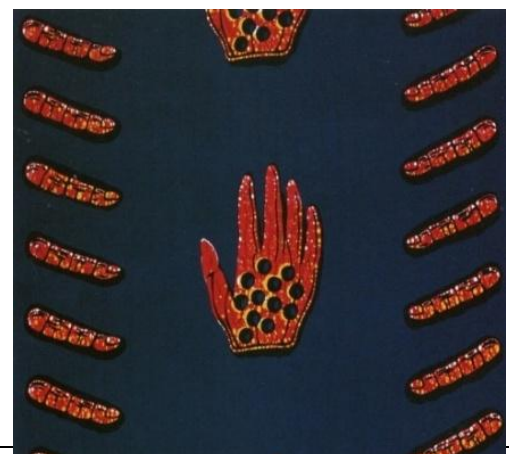

www.iosrjournals.org 
Plate 1:This same image conveys a different story depending on the context. Six Bougies is a cotton 'Dutch Wax' fabric first created for the West African market in 1940. This design features motifs and the text ' 6 Bougies', means ' 6 spark plugs' in French. It signifies social status, the prestige of owning a powerful car requiring 6 spark plugs to operate associating yourself with this image by wearing it would perhaps be inspirational or meant to publicly

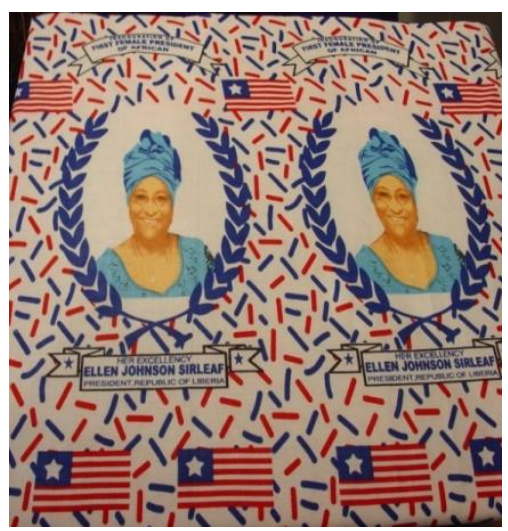

Plate 2: This wrapper design is one of the earliest designs still used today. It incorporates fingers, coins, and hands which symbolizes a Ghanaian proverb that roughly means, "'if you do it alone, you will fail, but if you work together you can make money'. It also refers to the Akan proverb, "the palm of the hand where money is received is sweeter than the back of the hand.

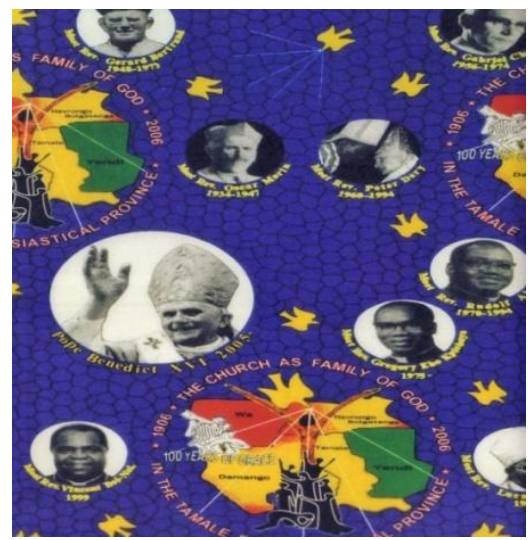

Plate 3 \& 4: The commemorative cloths have become increasingly important as political tools as well as to distribute educational or public religious information.

\section{Adaptation of Aquatic Forms For Textile Design}

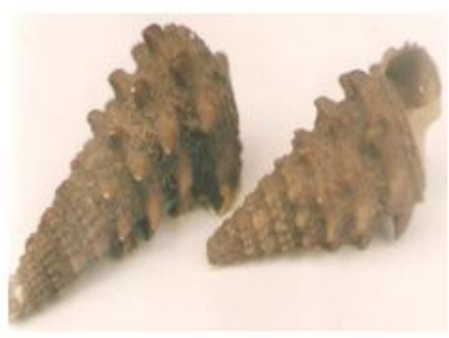

Plate 5: Periwinkle (Ngaru Isemi)

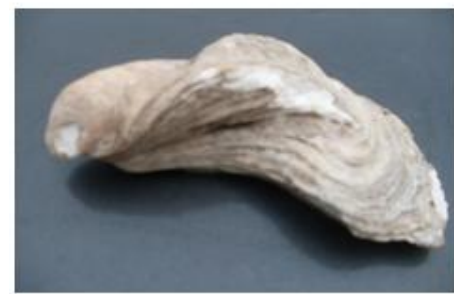

Plate 8: Oyster (Ingba) Collected from the Atlantic coast of Okpoama
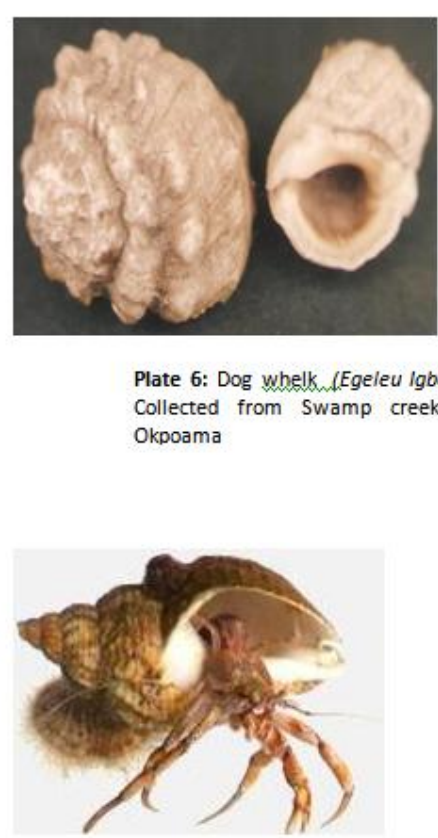

Plate 6: Dog whelk (Egeleu lgboun): Plate 7: Salt water fishes.

Collected from Swamp creeks of Source: Okpoama

Plate 9: Hermit Crab (Ifin)Photo from, Dorling Kindersley MicrosoftEncarta2009.8) 1993-2008 Microsoft Corporation.
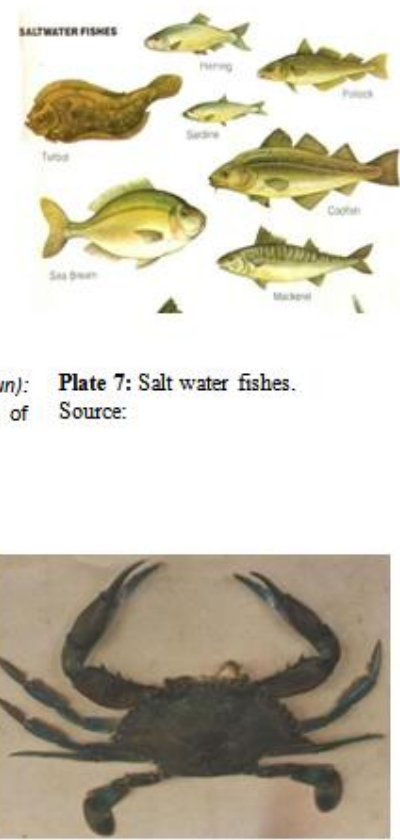

Plate10: Salt water Crab (Ikoli):collected from Okpoama

\section{Analysis of works}

Aquatic forms collected as resource from parts of the Nembe se in the Eastern Niger Delta region of Nigeria, were used for the production of textiles, depicting the environment, culture and history. The Niger Delta state include Abia, Akwa Ibom, Bayelsa, Cross Rivers, Delta,Edo, Imo, Ondo and Rivers States. This research has 
been able to identify some cultural heritage belonging to each of these states which could portray them for sustainability, but are not seen as that. Such cultures can use textiles as an alternative source for documentation and same preserved in places. In Abia and Imo states, they have the body scarification uli for body decoration, which is out of place now. Apart from some old photographs, that art is completely gone into extinction. They also have akwete cloth which is similar to the Akwa ocha of the Delta people but only recomended designs are produced because of the market demand. In Akwa Ibom, there are women festivals and raffia craft, Cross Rivers have the Ikom monolite that is gradually being affected by hash weather. Edo state has maintained their court art culture which has helped to preserve their heritage. These could be documented on textiles for a wide consumption. This has kept them on the map of prominet art costudians in Africa and a place that has value for tourism. Bayelsa and Rivers State have valuable art pieces but because they do not have court art practices, most of these works are taken out without documentation. If such works are identified and documented on textiles it will go along way to promote the culture. However, the area of interest in this paper is the riverine communities of the Niger Delta region. According to Cyril-Egware (2006) the riverine environment has a lot of hidden wealth other than petroleum products. The aquatic forms in the area have not been properly explored, studied and adapted for economic development and empowerment of the people of the Niger Delta. To this effect therefore this study picks the sea shells, fishes and their aquatic environment which are uncommon to use as motif for the unique textile design. The Nembe se towns were chosen for this study. The Nembe people however are not known textile producers, rather they use any fabric or dress as their traditional attire at formal and informal occasions. This will help to elevate their interest in the production of textiles. Man is very perceptive and influenced by natures creatures, forms and environment as well as its products. The adaptation of aquatic forms for an innovative design of this sort into the Nembe arts and culture is most welcome, as it is documentation of history on fabric.
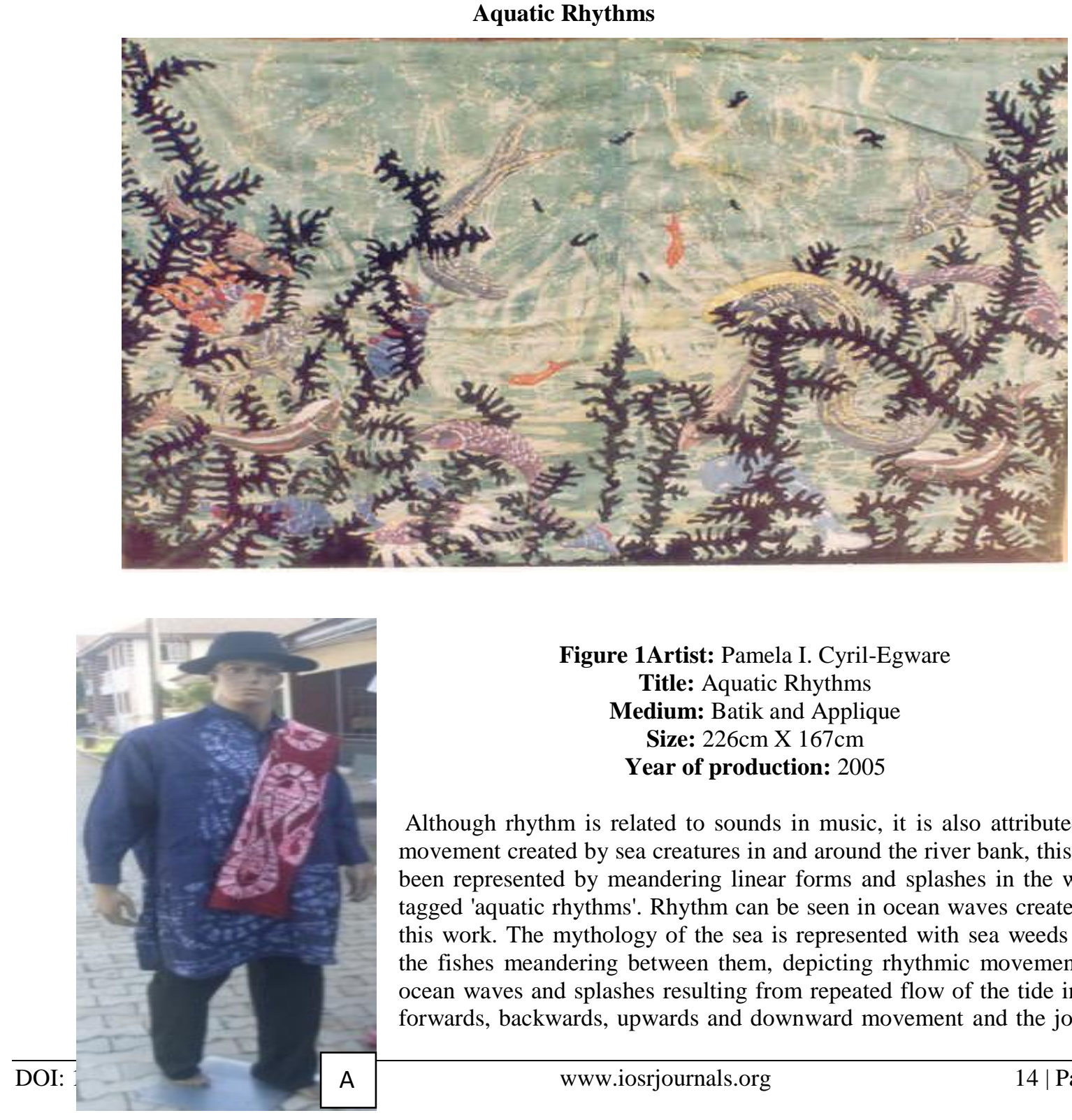

Figure 1Artist: Pamela I. Cyril-Egware

Title: Aquatic Rhythms

Medium: Batik and Applique

Size: $226 \mathrm{~cm} \mathrm{X} 167 \mathrm{~cm}$

Year of production: 2005

Although rhythm is related to sounds in music, it is also attributed to movement created by sea creatures in and around the river bank, this has been represented by meandering linear forms and splashes in the work tagged 'aquatic rhythms'. Rhythm can be seen in ocean waves created in this work. The mythology of the sea is represented with sea weeds and the fishes meandering between them, depicting rhythmic movement of ocean waves and splashes resulting from repeated flow of the tide in its forwards, backwards, upwards and downward movement and the joyful 
display of the fishes. There are reflections in the entire composition which makes reference to the real reflections created by the moon and stars at night on the sea. Iron-on stones are spattered on designated parts of the work to get that effect and used to represent the eyes of the fishes. The aquatic forms are rendered in nearly realistic forms with linear designs design. This is a representation and documentation of the aquatic environment, history and tale of the riverine communities in the Niger Delta region of Nigeria produced as textile design for wall hanging.

\section{Ama kiri Ikara(Excavated periwinkle shell)}

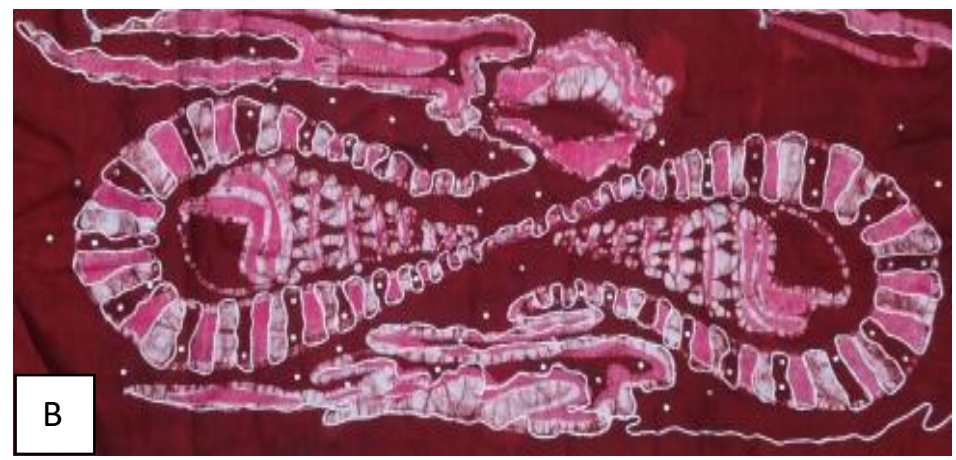

Figure 2 A\& B: One unit of the full fabric design of ama kiri ikara and also used as shoulder (a representation of ikagi bite) cloth by chiefs in the riverine communities.

Artist: Pamela I Cyril-Egware

Title: Ama kiri Ikara (Excavated periwinkle shell)Medium: Batik\& Lacing Year of production: 2012

Amakiri ikara is a representation of the history and culture of the Nembe people of Bayelsa state in the Eastern Niger Delta of Nigeria. It is historically known that only Nembe people the world over do not sell periwinkle. It is a taboo to sell it. It is eaten or given out as gifts but not sold. If a Nembe person sells the periwinkle (take note, not the shell), the black scale (isemi eperi) on its face will grow on the person's skin until he or she is cleansed and healed or death is inevitable. Onokuma Okolai, a 70 years old woman whom was interviewed by this researcher in Okpoama narrated a real life story of a lady she met several years ago at Oromabiri in Nembe who was affected by the sale of periwinkle, and so went for cleansing and healing. She said if the lady confesses she might be healed, but that she finished with what she went for and left so she does not know what happened to the affected lady after that. Some Nembe towns are also said to have a periwinkle festival (Isemi Olali). This makes it symbolic for the periwinkle to be clearly portrayed on the Nembe cloth to identify them. Ama kiri ikara (excavated periwinkle shell) is whitish, showing old age. That is said to provide spiritual protection for the Nembe person. It avert danger if put in the pocket or within and around the house, or as a decorative piece in the house. Personal communication with Edmund Ayerite (July2010); Onokuma Okolai (July 2011). Beredugo-Elei (November 2011), Diete-Kien, P.D (August 2011); Okorobia, Atei M. (November 2011).

Archaeological excavations according to Okorobia (2011) in an informal discussion showed that the periwinkle shell (isemi ikara) is found in every layer of the soil during excavation depicting Nembe settlements. Though a lot of mussels are found at sea formed by most of the sea shells, the periwinkle shell is always more as part of it. The periwinkle shell is used for construction of houses, bridges and roads. Properly dug and constructed wells for drinking water were casted with periwinkle shells. Late Rev. Can. M. H. D. Abaye and Late Sambo, Late Goldie of Okpoama built their houses, casted with periwinkle shells. The emphasis on the periwinkle was in the three communities, so it became inevitable to remove the abstract of the whelk shell (oloko ikara). The periwinkle shell is enclosed by linear forms depicting the aquatic environment and portrays an imagery of an island represented with a semblance of a zoomorphic royal python (ekekoru), in meandering horizontal form which embody segmented lines. The segments make reference to the three communities where this research work was carried out and is still ongoing, namely Nembe, Okpoama, Brass and Odioma which are located in Nembe Se island. Ekekoru is a totem of Ogidiga, introduced to Nembe from Itshekiri, and has grown from being a war-god to becoming a Nembe national deity. The Nembe consider it harmless and devotees see it as their father. Its temples are at Oromabiri and Sikaka-polo in Bassambiri quarters of Nembe city. It is forbidden to kill it. Okorobia (2011).

The periwinkle shell is rendered in a conical shape with tiny triangles representing thorns, and lines, giving it a textured effect. The mythology of the sea is represented with wavy lines depicting rhythmic movement of ocean waves resulting from repeated flow of the tide in its movement, with silk thread. There are reflections in the entire composition which makes reference to the real reflections created by the moon and stars at night on the 
sea. Iron-on stones are spattered on designated parts of the work to get that effect. Finished textiles may be used as dress design while a sample of the motif could be framed and kept as wall hanging.

\section{Unity in Diversity}

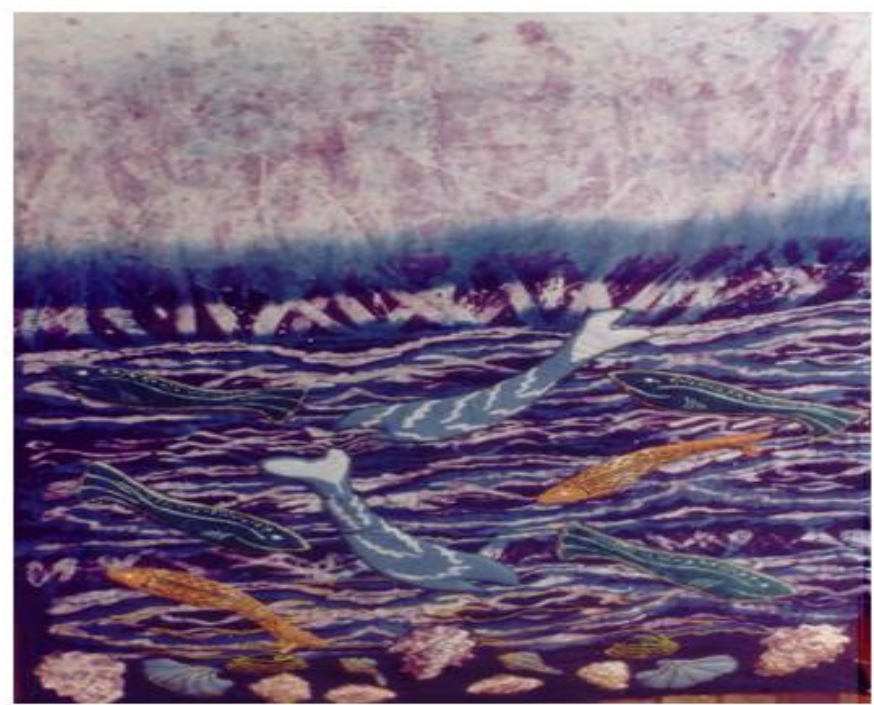

Figure:3

Artist: Pamela I. Cyril-Egware

Title: Unity in Diversity

Medium: Batik and applique

Size: $170 \mathrm{~cm}$ X $110 \mathrm{~cm}$

Year of production: 2005

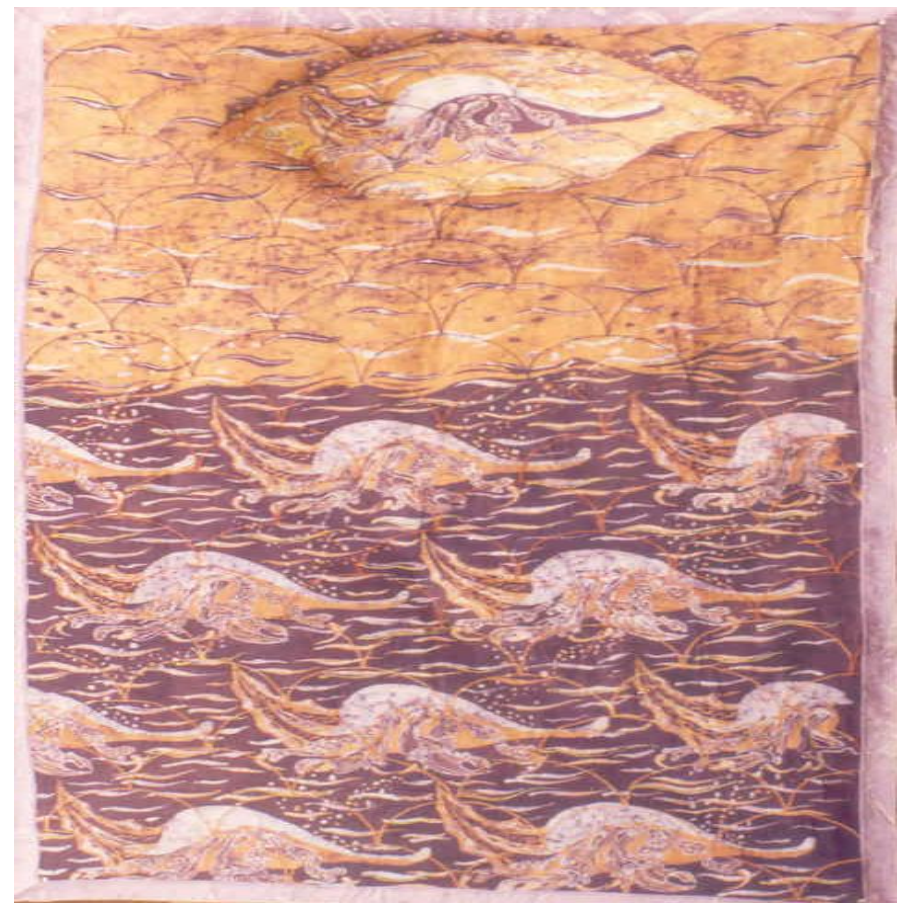

A friendly atmosphere brings unity, peace, joy and satisfaction. This can be seen in the different aquatic creatures that live in harmony in the aquatic environment, even though they are different in nature. The fishes and shellfishes live together and feed on each other, but nature has brought them in friendliness in their environment, so they cannot leave without each other, as they cannot survive. The Ijaw man fits in anywhere he finds himself and lives in total friendliness with everyone he meets in his new settlement, as far as human beings survive there. That goes on to justify a line in the old Nigerian anthem which states, "though tribe and tongue 
may differ, in brotherhood we stand". Unity in diversity is rendered in cool colours representing the peace in a united environment. It is a textile design used for a wall hanging.

Ifin(Hermit crab)Figure:4Artist: Pamela I. Cyril-Egware

Title: Ifin (Hermit crab)Medium: Batik Quilt Size: $170 \mathrm{~cm} \mathrm{X} \mathrm{110cmYear} \mathrm{of} \mathrm{production:} 2005$

Ifin (hermit crab)is one of the aquatic creatures that have its own shape, form and size as it lives in its environment. It lives in the empty shells of dead shellfishes such as periwinkle shell, dog whelk shell and so on according to their size. At a certain stage, it leaves the smaller shell for a bigger one when it grows too big for its current space. Conceptually, this movement of the Ifin from one shell to another shows the liberality and accommodativeness of the Nembe people of Bayelsa state in the Eastern Niger Delta. Ifin in this work shows that it has grown bigger than the periwinkle shell and other smaller shells and is living in an oloko shell still in the aquatic environment. Ifin is not eaten but can be used to hunt other sea creature like fishes with a hook or trap. The natural designs on the shell and the movement has inspired this work to be produced as a documentation of the accommodative culture of the Niger Delta people. This textiles is produced as a mat and a pillow taking the shape of a salt water crab. The half drop repeat method was used to finished the mat with batik and quilting technique.

\section{FINDINGS}

Nigeria has a rich cultural tradition in its textile craft locally and internationally. Textiles being a very mobile art could serve as an alternative medium for preserving the cultural heritage and environment of the people as clothing, decorative pieces and souvenirs. It is therefore established in this research that adapting designs inspired by the Niger Delta cultural heritage and environment on textile design will highlight, document, promote and preserve the peoples culture and enrich the decorative textiles in the local and international homes and public places. This will in turn promote tourism, industry and jobs for sustainable economic development. The design on plate 1 conveys a different story from what is visible. The wrapper is tagged Six Boogies, a cotton "Dutch Wax" fabric first created for the West African market in 1940. This design features motifs and the text "6 Boogies" which means "6 spark plugs" in French. It signifies social status, the prestige of owning a powerful car requiring 6 spark plugs to operate. Associating yourself with this image by wearing it would perhaps be inspirational or meant to publicly underline the fact that you owned one of these prohibitively expensive vehicles.

This wrapper design on plate 2 is one of the earliest designs still used today. It incorporates fingers, coins, and hands which symbolizes a Ghanaian proverb that roughly means, "if you do it alone, you will fail, but if you work together you can make money". It also refers to the Akan proverb, "the palm of the hand where money is received is sweeter than the back of the hand". Plate 3 and 4 are commemorative cloths which have become increasingly important as political tools as well as to distribute educational or public and religious information. These are inspirational fabrics that are designed for the environment, disseminating information, but with representational motifs.

\section{CONCLUSION /RECOMMENDATION}

The value of History and Fine Arts have been down played in the Nigerian school's curriculum in recent times. This has to be revitalized to keep track of our cultural heritage. In so doing, the value of Fine and Industrial Design will be appreciated as a medium for preserving the cultural heritage as resource for sustainability in the Niger Delta Region. At this level therefore, designs inspired by the peoples culture and environment will be emphasized for preservation and sustainability.

No society can develop and function effectively socially, politically, economically, technologically, industrially, educationally, religiously and aesthetically without textiles and fashion. The History of the world can be read in textiles design and contribute a lot in projecting people's culture. It conveys the cultural occupation and activities of the society. It can be used to determine cultural values belief, taboos, norms and geographical features of any ethnic group. Empowerment involves the emergence of entrepreneurship education as a tool for empowering the Niger Delta Youths. This can be achieved in textiles as a vocational course. There can be an overall sustainable development if youths in the Niger Delta are meaningfully engaged and gainfully employed and the region is industrialized. The production of textiles is a strong tool for empowering the youths, in the Niger Delta and the nation at large economically to help curb restiveness, reduce poverty, creates wealth through employment and highlights the region for tourism and industrialization.

Cyril-Egware(2013), state that Textile design is an area of the visual Arts with necessary creative skills and economic value which will inculcate in the youths proper education for self reliance and job security. Textiles encompass every human endeavour, without which the world will go naked. It includes clothing, furniture and soft toys. Ogunsiakan (2002) opines that textiles in several ways have shown that their importance to man particularly to Nigerians is prosperous and can alleviate the poverty syndrome that Nigerians have witnessed over the years. The production of textiles is a strong tool for empowering the youths, in the Niger 
Delta and the nation at large economically to help curb restiveness, reduce poverty, creates wealth through employment and highlights the region for tourism and industrialization.

This could be encouraged through many possible means in order to explore all potentialities for the purpose of creating employment opportunities for the youths and for boosting tourism, traditional industry in Art and Design, especially in textiles. This could be achieved by reviewing the school's curriculum and making History and Design compulsory at a certain level. Industries and Centres for textile Design could be established and such centres affiliated to Art schools to add formal educational strength to the products and not just for commercial purposes. There could be constant educating of the people on aesthetic and functions of textiles as an alternative source of documenting their cultural heritage, through regular exhibitions in city halls, Television, museums, art galleries and at local and international trade fairs. Local costumes with motifs, documenting the, culture and environment should be used at carnivals, and at traditional and cultural festivals and displays. Designs on figures 1, 3 and 4 could be use as stage backdrops at fashion shows and stage displays locally and internationally to identify participant on stage at every given time. The tourism sector should collaborate with the ministries of science and technology and the Bank of Industry to move their effort to villages outside the state capital. The white man did not concentrate on big cities when he came to introduce religion and education to us, if he did most people would have remained illiterates.

\section{REFERENCE}

[1] Alagoa, E. J. (1999) Traditions of origin: The Land and People of Bayelsa State; ed Alagoa E. J. and Derefaka, A. A. Onyoma Research Publications, Port Harcourt, Rivers State.

[2] Anderson, M. G. (1999), Visual Arts. The Land and People of Bayelsa State, Ed by E. J. Alagoa, Onyoma

[3] Research Publications, Port Harcourt.

[4] Bell-Gam, H.L. (2008), Creative Arts and the Future of the Niger Delta: A case study of Bayelsa State. History Concourse 2007. The Future of the Niger Delta: The search for a Relevant Narrative ed. Derefaka A. A. and Okorobia A.M. Port Harcourt: Onyoma Research Publications.

[5] Derefaka, A. A.(2012),The Management and Use of Cultural Heritage in the Niger Delta: The Bayelsa Example. History Concourse 2011. The Niger Delta Environment as Resources and Reserve. Edited by Ebiegberi Joe Alagoa, Bio Louis Nyananyo and Alfred Allison. Onyoma Research Publications, Port Harcourt, Rivers State, Nigeria.

[6] Cyril-Egware, P. I (2006), Art and Environment: An Adaptive Study of Aquatic Forms in Riverine Communities

[7] of Bayelsa State For Textile Design. A Project Submitted to the Department of Fine and Applied Arts,

[8] University of Nigeria, Nsukka in Partial Fulfilment of the Requirements for the award of the Degree of

[9] Master of Fine Arts (MFA)Textile Design.

[10] Cyril-Egware, P. I (2013), Twins inspired Textile Design for sustainable Development in the Niger Delta.

[11] Research, Innovation \& Development. International Journal of Research, Innovation \& Development. A

[12] publication of Uniport Research Fair and conference committee of Port Harcourt. Vol. 1. Issue 2.

[13] Talabi, G. (1979), Art Teaching in African schools. Heinemann Educational Books (Nigeria)

[14] LTD, Ibadan.

[15] Uzoagba, I. N. \& Olorukoba, B. K. (1991), Art History for Schools \& Colleges Book Two. Art Cultures of West

[16] Africa and the Congo. UNICA Arts Publishers, Nsukka, Nigeria.

[17] Ogunsiakan, T. (2002), Alleviating Poverty Through Self Reliance: Textiles Production Option. Design History in Nigeria, Essays in Honour of Demas Nwoko, Edited by Agberia, J. T National Gallery of Arts, Abuja and Association of Industrial Designers, Emhai Press, Uniport.

[18] Ojo, B. (2002), Textile Art And Design: A reappraisal of its scientific relations. Design History in Nigeria, Essays in Honour of Demas Nwoko, Edited by Agberia, J. T National Gallery of Arts, Abuja and Association of Industrial Designers, Emhai Press, Uniport.

[19] Okorobia, A. (2011) The Nembe: His origins and Heritage. A challenge to the Nembe Youths. Being a message to the National union of Nembe-Ibe students, University of Port Harcourt chapter on the occasion of their Annual student's union week on Saturday 24th September 2011 at University of Port Harcourt, Choba.

\section{[20] Oral Interviews}

[21] Beredugo-Elei (November 2011) Chief in Okpoama

[22] Diete-Kien, P. D (August 2011) Chief in Nembe

[23] Edmund Ayerite (July2010) Elder in Okpoama

[24] Okorobia, Atei M. (November 2011) Historian and researcher in Niger Delta History.

[25] Onokuma Okolai (July 2011) Elder in Okpoama 